\title{
BENCANA DALAM SEJARAH
}

\author{
Disaster in History
}

\author{
Susanto Zuhdi \\ Departemen Ilmu Sejarah Fakultas Ilmu Budaya, Universitas Indonesia \\ E-mail: susanto_zuhdi@yahoo.com
}

\begin{abstract}
Disaster had become inseparable with life of mankind within the trajectory of history, more due to its correlation with the adaptation we made toward changes in nature. This article discussed the effect of natural disaster to the existence of the living, specifically in Dutch East Indies in the colonial era. Questions were put forward to particularly understand the impact of volcanic eruptions, plagues, and climate changes toward societies living inside of the colony, including how they managed to cope with the challenges. Moreover, this article gave further analysis on the significance of past occurences to the present and the future. The method used in this article is the method of historical writing, which allowed historians to work on archives and contemporary documents, to eventually interpret history as it is.
\end{abstract}

Keywords: volcanic eruption, tsunami, plague, Dutch East Indies.

\begin{abstract}
Abstrak
Bencana menjadi tidak terpisahkan dari kehidupan manusia dalam lintasan sejarah, terlebih dalam kaitannya dengan adaptasi yang dilakukan terhadap perubahan alam. Makalah ini membahas bencana alam yang berdampak pada kehidupan manusia, khususnya masyarakat Hindia Belanda pada masa kolonial. Pertanyaan diajukan untuk mengetahui secara partikular mengenai dampak bencana, seperti erupsi gunung, pandemi, dan perubahan ilkim, terhadap kehidupan di tanah jajahan. Termasuk juga bagaimana pemerintah kolonial menanganinya. Lebih jauh lagi, makalah ini turut menggali makna dari peristiwa di masa lampau bagi kondisi saat ini dan yang akan datang. Metode yang digunakan dalam makalah ini adalah metode sejarah, yang memungkinkan makalah ini disusun berdasarkan arsip dan dokumen sezaman yang ditemukan, ditelaah, dan diinterpretasi.
\end{abstract}

Kata kunci: erupsi gunung, tsunami, wabah, Hindia Belanda.

\section{PENDAHULUAN}

Nothing new under the sun: "tidak ada hal baru di bawah matahari". Begitu adagium sejarawan untuk mengatakan pada prinsipnya ada pola yang berulang dalam sejarah. Dilihat dari tempo yang panjang (longue duure) menurut Braudel, kita dapat mengidentifikasi kesinambungan isu-isu atau masalah utama yang dihadapi manusia.

Selama ribuan tahun sejarah yang sudah dilewati manusia masih tidak beranjak dari tiga masalah yang masih berulang dan tetap tidak berubah: kelaparan, wabah, dan perang. Demikian Yuval Noah Harari mengawali tulisannya dalam buku Homo Deus (penerjemah Yanto Musthofa, 2019). Kelaparan terjadi karena berbagai faktor. Bencana alam berupa erupsi gunung yang menyebabkan rusaknya lahan pertanian dan 
perkebunan atau faktor cuaca juga dapat menyebabkan kekeringan sehingga berdampak pada kegagalan panen. Adapun wabah penyakit berupa epedemi atau pandemi.

Dampak dari erupsi gunung berapi yang sering terjadi di tanah air kita, hampir dapat dipastikan terjadi berulang atau secara silih berganti. Mengapa hal itu bisa terjadi karena posisi wilayah negeri ini berada dilingkari 'cincin api' (the ring of fire). Gejala alam berupa tsunami pun merupakan hal 'biasa' dalam arti kejadiannya sudah berulang kali, meskipun dengan skala yang berbeda-beda. Tsunami (bahasa Jepang tsu=pelabuhan; nami=gelombang) atau yang dalam bahasa Aceh disebut iebeuna (ie= air; beuna = bah") pada 2004 (Zuhdi 2006) merupakan peristiwa alam yang paling besar sepanjang sejarah. Tetapi dalam skala lebih kecil dalam dekade terakhir beberapa kali tsunami juga di pantai barat Sumatera: Padang, Bengkulu, dan Pangandaraan di selatan Jawa. Selain yang disebabkan oleh gejala tektonik di dasar laut, tsunami juga bisa disebabkan karena erupsi gunung berapi.

Makalah ini membahas bencana alam yang disebabkan erupsi gunung, karena pandemik, dan perubahan iklim ekstrim yang berdampak pada kehidupan dalam masa kolonial Hindia Belanda. Apa yang terjadi dan akibatnya bagi kehidupan masyarakat jajahan dan bagaimana kebijakan pemerintah dalam menangani masalah tersebut. Apa maknanya bagi kehidupan manusia dalam menyikapi alam pada saat dan sesudah peristiwa.

\section{PEMBAHASAN}

\section{Erupsi Gunung Krakatau 1883 dan Tambora 1815}

Satu di antara gunung di Indonesia yang sering erupsi adalah Krakatau. Dari karakter Krakatau adalah kepulauan vulkanik, yang terdiri dari gunung 'induk' dan 'anak-anaknya' semuanya berpotensi meletus dalam berbagai skala. Pada tahun 2018 (3 Agustus) Anak Krakatau meletus lebih tigaratusan kali. Kemudian pada 25 September 2018 Anak Krakatau meletus 99 kali memuntahkan lava ke laut dan menimbulkan tsunami ke pantai barat Banten dan Lampung. Letusan terbesar Krakatau dalam sejarah terjadi pada 1883. Erupsi ini menghilangkan gunung induk. Sebagai kepulauan vulkanik yang terus aktif menghasilkan anak-anak baru Krakatau. Letusan cukup besar pada 22 Desember 2018 mengakibat tsunami menghantam pantai barat Banten dan Lampung. Letusan kecil terjadi menimbulkan beberapa korban tewas dan banyak kerugian materi.

Sartono Kartodirjo mencatat bahwa rakyat belum sempat bangun kembali dari semua penderitaan itu, ketika letusan dahsyat Gunung Krakatau dalam tahun 1883 yag mengakibatkan kehancuran hebat. Lebih dari 20.000 orang tewas, banyak desa yang makmur hancur dan persawahan yang subur menjadi gersang. Timbul masalah kesehatan pada masyarakat seiring akibat letusan Krakatau, yaitu merebaknya wabah penyakit ternak dan wabah demam serta kelaparan. Populasi ternak merosot jumlah pekerja berkurang sehingga sepertiga dari tanah pertanian tidak dapat ditanami dan akibat erupsi Krakatau menyebabkan luas tanah yang tidak dapat digarap lebih besar lagi, terutama di bagian barat afdeling Caringin dan Anyer. Kegagalan panen selama 
beberapa tahun antara 1878-1886 akibatnya lebih buruk lagi (Kartodirdjo, 1984 :9394).

Sartono hanya sedikit mengulas erupsi Krakatau dan dampaknya terhadap masyarakat keculai keadaan umum sosial ekonomi penduduk. Sikap pemerintah Belanda terhadap kondisi masyarakat pascaerupsi Krakatau, dicatat oleh A.B. Lapian dalam tulisan mengenai hubungan bencana alam dengan historiografi. Pemerintah kolonial memandang situasi pasca erupsi Krakatau dengan akibat yang ditimbulkannya justru dengan sikap cemas dan waspada. Ini tentu saja dapat diterima. Agar masyarakat kembali tenang, pemerintah Belanda memberikan bantuan kepada masyarakat di Banten berupa uang sebesar 4000 gulden yang kepada sepuluh desa untuk mengadakan 'sedekah', yaitu dengan mengadakan semacam kenduri untuk mendoakan "kassalamettan die dalam negrie Bantam tidak bertemoe lagie atawa mendapet lagie katjilakahan sebage iang soedah kedjadian" (Lapian dalam Alfian, 1987:224).

Bagi kalangan masyarakat Belanda seperti pandangan yang ditulis R.A. Saddick, peristiwa yang menenggelamkan aristoraksi pribumi di Caringin itu dipandang sebagai "oud-testamentisch wraakgericht" suatu hukuman seperti yang digamabrkan dalam Perjanjian Lama dari Kitab Injil. Bagi masyarakat Banten yang masih berpegang pada tradisi, Krakatau meletus karena dilangsungkannya secara bersamaan antara acara pernikahan dan khitanan keluarga bupati Caringin dengan tontonan tayuban (Lapian 1984:220-221).

Dampak erupsi Krakatau terhadap kehidupan masyarakat Banten. Laporan Residen Banten dalam Javasche Courant 5 Oktober 1883, dalam tempo dua bulan sebagian besar dari daerah itu telah pulih kembali dari berbagai kerusakan (Kartodirdjo, 1984: 106). Tentu tidak begitu saja diterima, mengingat beberapa tahun kemudian meletus pemberontakan petani di daerah ini. Secara tidak langsung penanganan pemerintah dalam mengatasi dampak erupsi Krakatau tidak menghasilkan kepuasan masyarakat.

Dibanding letusan Krakatau, dampak erupsi Gunung Tambora yang meletus pada 1815 jauh lebih besar korban yang ditimbulkan. Pada 1815, kepulauan Indonesia berada di dalam masa pemerintahan sementara yang dikuasai pmerintahan Inggris di bawah Letnan Jenderal Th. Stanford Raffles, sebelum akhirnya diserahkan kepada Belanda tahun berikutnya. Sumber pertama mengenai letusan Tambora berasal dari karya Raffles berjudul "Narrative of the effects of the Eruption from the Tomboro Mountain, in the Island of Sumbawa, on the $11^{\text {th }}$ and $12^{\text {th }}$ of April 1815". Artikel ini merangkum laporan dari para pejabat di daerah di Nusantara. Letusan Tambora semula diduga di Jawa, Sumatera, sulawesi atau Kepulauan Maluku. Dari Yogyakarta dikirim suatu detasemen meriam diduga pos terdekat diserang, atau diduga benteng Marlborough di Bengkulu. Sebagai fakta tiga kerajaan lenyap dari muka bumi yakni Sanggar, Papekat, dan Tambora. Penduduk Pulau Sumbawa turun drastis. Tercatat 84.200 orang tewas termasuk yang mengungsi (Sjamsuddin 2013:79).

Bagaimana manusia menjelaskan dan memahami serta memaknai peristiwa katastrofik menarik diamati. Bahan renungan atas perbuatan manusia yang dianggap 
sebagai penyebab. Atau peringatan dari Maha Kuasa atas tindakan keliru atau menyimpang dari ajaranNya. Dalam kaitan itu menarik menyimak beberapa bait syair (Chambert-Loir, 2004:267-269).

Kejadian alam diterima sebagai takdir.

\begin{tabular}{|l|}
\hline Adalah hujan lalu tertanam \\
\hline Padinya jadi sangatlah kelam \\
\hline Datanglah takdir Khalik al-Kalam \\
\hline Turunlah abu dua hari tiga malam \\
\hline
\end{tabular}

Takdir memang diyakini sebagai kepastian karena datangnya dari Tuhan, tetapi juga karena perilaku manusia yang tidak mentaati ajaran Tuhan untuk berbuat baik. Jadi peristiwa ini dipandang sebagai 'hukuman'.

Sultan Tambora Abdul Gafur

Barang pekerjaannya sangatlah takabur

Tiadalah percaya riwayat dan tutur

Negeri dan badan menjadi lebur

\section{Pandemi Flu Spanyol 1918}

Petaka besar karena pandemi demam (flu) yang dicatat dalam sejarah dunia dan berimbas ke negeri jajahan Hindia Belanda terjadi pada 1918. Pandemi influenza 1918 menyebar secara luas sampai ke Hindia Belanda pada akhir 1918 dan awal 1919, penyebaran cepat dan massal virus influenza tipe A dengan subtype $H 1 \mathrm{~N} 1$ merebak ke seluruh dunia. lebih banyak menewaskan orang disbanding The Black Death dalam abad ke-14 di Eropa. Pandemi influenza membunuh banyak orang dalam 24 minggu dibanding penyebaran AIDS selama 24 tahun. Perkiraan 20 sampai 40 juta orang tewas. Angka tersebut masih perkiraan karena di India 20 juta dan Cina 10 juta korban meninggal. Pandemik ini dianggap berasal dari Amerika Serikat pada Maret 1918. Ditemukan di Eropa pada pertengahan 1918 dibawa oleh pasukan resimen Amerika Serikat cepat menulari tentara Prancis dan Inggris. Kemduain merebak ke Spanyol, negara yang sebetulnya netral dalam Perang Dunia Pertama. Jusrtu kemudian lebih dikenal dengan istilah Flu Spanyol karena sebagai negara yang netral bebas mengumumunkan adanya pandemik, sedangkan pada negara yang terlibat perang melakukan sensor, menutup berita tersebut dalam waktu tiga bulan penduduk Eropa dua setengah juta tewas. Kemudian menyebar ke keluar Eropa, Afrika Utara, Asia, Cina, India, Filipina, Selandia, Baru, dan Hawaii.

Di Surabaya, wabah demam pernah terjadi pada janurai 1910, meskipun peningkatannya tidak setinggi Batavia, merupakan ancaman yang harud diwaspadai. Begitulah maka residen Surabaya telah menyiapkan dana 1000 gulden untuk penanggulangan wabah flu. Di Batavia disediakan 12000 gulden tidak cukup untuk 
pekerjaan pengeriangan rawa-rawa, karena itu tidak mau lagi mengajukan kepada gubernur jenderal (Wibowo dkk, 2009:85).

Pada Juli-Oktober 1911 wabah demam menyerang Semarang. Penyebaran dimulai dari Pelabuhan karena itu disebut "haven malaria". Perusahaan perkapalan KPM dan dokter karantina Pelabuhan Cirebon,menilai bahwa pemerintah Cirebon telah melakukan kecerobohan karena mengabaikan tingkat bahaya penularan penyakit melalui aktivitas perkapalan (Emalia, 2020:105)

Pandemi tahun 1918 yang merebak ke seluruh dunia merupakan ancaman paling serius daripada yang pernah terjadi sebelumnya. Akan tetapi didalam menanggapi terkesan disikapi secara biasa. Memang dapat dimnegrtia ketika flu ini merebak Eropa sedang mengalami Perang Dunia Pertama. Sedangkan awal masuknya ke Hindia Belanda (Indonesia) pun tidak ditanggapi dengan serius. Mungkin karena dianggap hal biasa seperti wabah demam yang sebelumnya telah terjadi. ketika wabah menjalar ke Asia, Cina merupakan negeri yang pertama terjangkit. Karena hubungan pelayaran melalui pelabuhan Hongkong maka dengan begitu kemungkinan meluasnya wabah ke Asia dan Indonesia.

Pada April 1918, Konsul Jenderal Hindia Belanda di Singapura mengingatkan akan penyebaran wabah flu dari Hongkong melalui pelabuhan. Untuk itu agar dicegah kapal-kapal yang masuk dari Hongkong. Tindakan yang diambil hanya dengan memperketat pengawasan dan akibatnya dalam beberapa waktu kemudian pada Juli 1918, beberapa pasien dilaporkan dirawat di rumah sakit. Secara berturut laporan diperoleh dari beberapa daerah, dari Banjarmasin pada November tahun itu juga diinformasikan telah terserang wabah influenza. Akhir November dari Buleleng dilaporkan banyak korban penduduk, dari Banyuwangi 2 Desember 1918. Kemudian menyebar Surabaya pada akhir November.

Tindakan berupa pengobatan dilakukan oleh pemerintah daerah. Penerangan akan bahaya wabah dilakuakn dengan menggunakan mobil "Dienst der Volksgezondheid Afdeeling Medisch-Hygienische Propaganda", di setiap kota yang telah mempunyai dinas Kesehatan Kota (Burgerlijke Gezondheid Dienst) (Wibowo dkk, 2009: 118). Laboratorium di Batavia telah menemukan obat berupa tablet influenza terdiri atas unsur 0,250 aspirin, 0,150 pulvis, dan 0,100 camphora. Produksi pertama dihasilkan 100 ribu butir tablet. Masyarakat di Jawa Tengah melaukan sendiri upaya pencegahan dengan meminum jamu-jamuan.

Pemerintah pada November 1918 membentuk tim yang diberi kewenangan untuk mengambil tindakan pencegahan dan penanganan untuk mengatasi pandemi. Rupanya tidak dengan mulus, karena beberapa instansi memperlihatkan ketidaksepakatan atas penanganan, terjadi konflik justru ketika sedang dalam puncak merebaknya pandemik. Meskipun kemudian dikoreksi tentang jumlah korban di Surabaya yang semula diberitakan hingga satu setengah juta, dan ternyata sekitar puluhan ribu orang. Itupun sudah merupakan angka yang tinggi. Soal informasi data yang akurat. menjadi penting dalam pengambilan kebijakan. Dokter de Vogel, ketua tim khusus penanganan influenza merancang undang-undang (Influenza Ordonantie) yang 
diselesaikan pada 1919 kemudian diserahkan kepada van Limburg Stirum. Gubernur Jenderal Hindia Belanda itu lalu membagikannya ke sejumlah instansi dan kalangan swasta. Reaksi muncul terhadap rancangan tetapi yang penting dicatat bahwa isu penanganan wabah telah menjadi isu politik bagi perjuangan politik masing-masing pihak yang berkepentingan. Diperlukan waktu hampir satu tahun untuk pengesyahan RUU tersebut (Wibowo dkk,2009: 126).

Reaksi keras yang memprotes datang dari pihak Perusahaan Perkapalan (Koninkelijke Paketvaart Maatschappij = KPM). Peraturan itu berarti membatasi ruang gerak kerja perkapalan dan pelabuhan di Hindia Belanda. Tidak mau dikatakan menghambat kegiatan ekonomi, de Vogel menegaskan bahwa karena penyebab utama penyebaran wabah dari aktivitas di pelabuhan. Penumpan yang datang dari luar (negeri) itulah pembawa (carrier) penyakit. Hasil riset de Vogel mempelihatkan bahwa paing banyak penderita mereka yang tinggal di kota-kota pesisir/pelabuhan.

Pembuatan undang-undang ini tentu sudah kuat karena berdasarkan pada peraturan yang sudah ada tentang Karantina tahun 1911. Peraturan ini memberi wewenang kepada kepala daerah untuk melakukan karantina pada daerah tertentu yang dinyatakan terkena wabah penyakit. Tujuannya untuk tidak menyebarkan ke daerah lain. Mereka yang melanggar peraturan ini akan dikenakan sanksi dan diberi hukuman pidana. Dalam konteks yang menurut de Vogel relevan bahwa peraturan ini juga dikenakan bagi wilayah Pelabuhan. Bukan itu saja nakhoda kapal, menurut implementasi peraturan ini dapat dikenakn sanksni karena dia paling bertanggung jawab atas apa yang terjadi di kapal. Oleh karena itu, seorang nakhoda menerapkan peraturan itu terhadap penumpang di kapalnya.

Namun KPM bereaksi keras atas atas pendapat de Vogel. KPM berpendapat bahwa bukan nakhoda yang harus bertanggungjawab tetapi syahbandar pelabuhan. Karena dia yang paling tahu siapa penumpang yang akan naik dan turun (dari daftar). Selain itu juga penting mengawasi para kuli yang bekerja pada waktu bongkar muat barang. Keberatan KPM tentang larangan penumpang transit turun ke dermaga dan harus tetap berada di atas kapal, akan mematikan perekonomian di sekitar pelabuhan. Di sini tampak dilema antara kesehatan dan kepetingan ekonomi. De vogel melaporkan hal ini kepada Gubernur Jenderal, karena alasan KPM itu dianggap dibesar-besarkan, seperti yang dikemukakan:

"Kebenaran dari dampak terakhir (hambatan-hambatan yang dialami oleh para pedagang yang berkeliling di kepulauan ini sebagai penumpang kapal-kapal dari sebuah Pelabuhan terjangkit influenza tanpa surat bebas influenza dalam mengelola perdagangan) masih perlu diragukan"(Wibowo dkk, 2009: 140).

Pengaturan kapal dan pelabuhan berikut awaknya belum juga tuntas sampai setahun lamanya. Panglima Angkatan laut membahwahi Departemen Kelautan Laksamana WJG Umbgrove turun tangan untuk mengatasi dua kepentingan berbeda 
antara KPM dan de Vogel. Sebetulmya kedua pihak mempunyai dasar yang kuat sebagaimana suratnya kepada Gubenrnur Jenderal:

"saya bisa menyetujui tujuan dan isi rancangan peraturan itu, tetapi bagi keberatan-keberatan yang diajukan oleh KPM terhadapnya, tanpa terkecuali bahwa karena larangan untuk menurunkan penumpang yang menyertainya, diperolehnya surat ijin bebas influenza bagi kapal-kapalnya praktis tidak mungkin dilakukan, sebaliknya saya bisa merasakannya" (Wibowo dkk 2009: 144).

Umbgrove berpendapat bahwa keberlangsungan KPM berperan besar bagi kestabilan dan kemajuan negara jajahan berupa kepulauan ini. Namun dipihak lain soal influenza juga merupakan ancaman bagi keselamatan armada laut itu sendiri. Umbgrove mengusulkan agar bukan hanya nakhoda saja tetapi juga pihak pelabuhan bertanggungjawab. Jadi semua pihak bekerjasama untuk mencegah penyebaran penyakit influenza, khususnya dipelabuhan-pelabuhan, pintu masuk ke daerah pedalaman. Masukan pemikiran itu kemudian diolah sebagai bahan perbaikan rencana peraturan tentang penyakit influenza rumusan de Vogel (Wibowo dkk, 2009: 146).

Cilacap, satu-satunya pusat pertumbuhan ekonomi Pelabuhan di Jawa bagian selatan dari masa Kulturstelsel hingga kedatangan Jepang 1942, juga memperlihatkan isu endemi malaria sebagaimana kota-kota pantai lainnya. Faktor Kesehatan sangat penting bagi Pelabuhan ketika berkurangnya tenaga buruh yang terkena malaria. Pada bulan antara Januari-Februari secara periodik menjadi kendala bagi aktivitas Pelabuhan. Upaya untuk pemberantasan penyakit menjadi hal mendesak untuk diatasi. Berdasarkan penelitian dokter van Swellingrebel dari Dinas Kesehatan Rakyat (Volksgezondheid Dienst) di Cilacap pada tahun 1917 jumlah anak antara usia 2- sampai 12 tahun tertular malaria sebanyak 38\% sampai $80 \%$. Dalam kesempatan lain, pemerintah melalui Departemen Pekerjaan Umum (Burgerljke Openbare Werken) mengirim H.G. Nieuwenhuijs ke Cilacap. Ia arsitek yang terkenal karena berhasil menangani malaria di Sibolga, Sumatera Utara. Dari hasil riset Swellingrebel itulah Nieuwenhuis menyusus rancangan kerja pembangunan kota Cilacap khususnya untuk memberantas malaria. Pada akhir tahun 1919 Pemerintah menunjuk L. Kailola untuk membantu Direktur Pelabuhan di Cilacap memulai pekerjaan berdasarkan rancangan H.G. Nieuwenhuis. Pekerjaan diarahkan pada lima kawasan di Kota Cilacap. Kemajuan awal yang dapat dicatat telah terjadi angka penurunan persentase penularan pada tubuh anak (Zuhdi, 2016:110-112).

Terkait pada isu wabah inluenza di Cirebon, pemerintah kota menolak larangan pemeriksaan di atas kapal yang bersandar di pelabuhan yang akan dilakukan oleh dokter karantina berdasarkan peraturan sesuai perosedur kesehatan. Kapal itu baru diizinkan merapat dan menurunkan penumpang serta membongkar muat barang setelah disterilisasi selama 50 jam. Keberatan pemerintah Cirebon karena untuk keperluan di atas sangat minim. Begitulah maka tidak ada alokasi dana misalnya untuk 
mengarantina kapal Linden dan awaknya yang sakit. KPM dan dokter karantina Pelabuhan Cirebon menilai pemerintah Cirebon telah mengabaikan faktor Kesehatan.

Dari koran"Bintang Tjirebon" terbetik berita:

“..sajang adoeh sajang. Di pelaboehan kita para boeroeh banjak jang menderita sakit kerna pamarentah teroes membangoen, menerima dan memberangkatken kapal barang tanpa memperhitoengkan kasihatan para boeroeh. Mereka tida sahadja sakit kolera dan demam malaria tapi pes. Wabah pes moentjoel akibat banjak bangke tikoes boesoek di goedang pelaboehan dan ada djoega di roemahroemah pendoedoek di sekitarnja"

Pada tahun 1912 sapai 1930-an selain wabah kolera, pes juga malaria menyebar ke sekitar pelabuhan dan daerah lainnya. (Emalia, 2020: 105-6).

Dalam periode akhir masa antara 1937 sampai 1940, pemerintah kolonial Hindia Belanda telah gagal untuk mengatasi masalah sosial-ekonomi di wilayah Bojonegoro. Sejumlah faktor yang menyebabkan adalah kegagalan panen, meluasnya gizi buruk, kelaparan dan penyakit yang berjangkit di kalangan penduduk. Masalah yang dapat dicatat diawali dengan rendahnya hasil panen jagung pada akhir tahun 1936. Selain itu juga kemunculan dalam jumlah besar walang penggerek di awal tahun 1937 yang meluluhlantakan hasil tananam, setelah itu disusul dengan musim hujan hingga Juli, sehingga tidak memunkinkan tanaman jagung dan tembakau. Disusul dengan masa kekeringan yang sangat hebat, sampai November menyebabkan hampir sepenuhnya mereduksi kegagalan tanamam jagung pada daerah non-irigasi dan sangat berpengaruh terhadap hasil tanaman tembakau Virginia. Suatu musim hujan lebat yang tidak normal pada Desember menyebabkan tanaman jagung dan tembakau krosok gagal panen.Mengutip laporan gubernur Jawa Timur, Penders mengemukakan (Penders, 1984:126) :

" banjir besar yang tak biasa terjadi dalam bulan-bulan selanjutnya.. bagianbagian luas lembah (Bengawan) Solo terendam air. Di daerah Bengawandero dan seluruh dataran rendah pusat Lamongan tidak mungkin dapat ditanami. Kira-kira 50 bendung irigasi-yang dibangun masyarakat sebagaimana yang dibuat Dinas Irigasi-hancur, yang berarti tidak ada irigasi selama musim (angin) timur".

Petaka yang harus dialami penduduk Bojonegoro karena iklim yang ekstrim ini masih ditambah dengan musim kering dalam bulan Maret 1938 menyebab hancurnya tanaman di wilayah perbukitan dan walang penggerek datang lagi penyebab kehancuran besar meskipun tidak sama seperti tahun 1937. Di akhir April tahun itu, hujan lebat turun kembali sampai pertengahan Agustus menyebabkan panen jagung gagal untuk yang keempat kali. Di samping itu benih-benih tembakau krosok di beberapa tempat 
tidak mungkin dapat ditanam sama sekali. Akibatnya perusahaan tembakau Virginia menderita, tetapi sedikit tertolong karena ada bantuan dari kebaikan British American Tobacco (BAT) untuk membeli dengan harga tinggi. Komentar singkat van der Plas atas kondisi ini "such a succession of disasters cannot be equally even in the history of Bojonegoro".

Akibat pada penduduk merupakan bencana dan Tindakan yang diambil pemerintah kolonial tidak efektif. Kekurangan gizi makanan menyebabkan meluasnya penyakit yang pada diagnosa awal sebagai terjangkit malaria, tetapi kemudian diketahui juga banyak yang terkena "beri-beri" (hunger oedema).

Pada 4 Februari 1937 pemerintah kolonial memberi bantuan 50.000 gulden untuk Bojonegoro, yang pada tahun itu meingkat menjadi 211.000 gulden. Ini termasuk untuk persediaan benih beras super, jagung, dan ketela (cassava). Sebagian uang itu juga untuk memperbaiki sarana seperti penggalian kanal dari Sungai Ingas. Akan tetapi, kemudian menjadi nyata bahwa masyarakat tidak dapat melakukan kerja berat dan bertahan lama karena sakit malaria meskipun tersedia obat kina.

Menarik untuk mengetahui hasil penyelidikan dokter Tumbelaka yang ditugasi pemerintah terkait dengan situasi pangan di distrik Dander, Sughwaras, Kedungadem, dan Kanor. Ia menyimpulkan terjadinya gizi buruk (malnutrisi) yang telah meluas. Dalam laporan itu memang tidak diragukan bahwa malaria sebagai faktor penting penyebab kesehatan masyarakat, tetapi daya tahan tubuh juga lemah karena gizi buruk. Bantuan untuk pangan justru digunakan oleh masyarakat untuk dijual atau untuk membeli benih tanaman. Mereka berharap dapat bekerja di fasilitas umum untuk mendapatkan upah untuk membeli pangan. Tetapi seperti dilaporkan Tumbelaka, banyak orang tidak mampu bekerja karena daya tahan fisik yang lemah karena penyakit.

Epedemik malaria mulai dibantu dalam kuartal ketiga tahun 1937 dan memuncak pada Mei 1938 sebagai akibat berlanjutnya musim hujan lebat. Situasi paling buruk muncul di distrik Baureno. Wedono (pembantu bupati) Baureno berpegang pada penyelidikan medis terbaru yang dilakukan dokter Tumbelaka yang mengunjungi Baureno hingga belasan kali dari Oktober dan Desember 1938. Selain malaria juga terdapat hunger oedema yang menimpa penduduk Baureno. Menanggapi kondisi seperti ini, van der Plas, Gubernur Jawa Timur mengatakan bahwa malaria merupakan penyebab mendasar sebagai masalah bukan hunger odema (penyakit beri-beri) (Penders 1984:129).

\section{SIMPULAN}

Terdapat nilai universal yang dianut manusia dalam menanggapi peristiwa katastrofik seperti yang terjadi pada peristiwa Krakatau dan Tambora. Manusia merasa begitu kecil dan tanpa daya kecuali Tuhan Yang Maha Perkasa. Manusia dapat bercermin dari kejadian itu sebagai pengingat dan pelajaran. Sebagai orang Nasrani, van Saddick memandang erupsi Krakatau sebagai "suatu hukuman Tuhan" sebagai digambarkan dalam Perjanjian Lama dari Kitab Injil. Bagi ummat Islam acuan yang 
dicari terdapat dalam Al-Qur'an yang mengisahkan banjir besar zaman Nabi Nuh (Noah) dan gempa yang menjungkirbalik bumi Sadum (Sodom) pada masa Nabi Luth.

Lalu bagaimana cara memandang kejadian yang tampak sebagai gejala alam seperti wabah pandemi atau paceklik berkepanjangan karena iklim. Tarik menarik kepentingan antara sektor kesehatan atau ekonomi sudah sejak lama menjadi perdebatan. Setidaknya dalam masa kolonial Belanda, seperti diperlihatkan antara kepentingan Perusahaan Perkapalan dalam urusannya dengan aktivitas di pelabuhan berhadapan dengan pemerintah daerah yang berusaha mencegah penyebaran wabah yang masuk.

Kajian mengenai gejala alam dengan berbagai bentuk dan karakternya sungguh menarik dan penting bagi pengembangan historiografi di Indonesia. Bukankah sudah seperti ditakdirkan bahwa nusantara ini berada di dalam "ring of fires" dan dilingkari dasar laut dengan patahan Indo-Australia. Itu artinya bahwa perubahan alam di masyarakat Indonesia merupakan keniscayaan. Sejarah bencana seperti itu dapat berulang karena faktor struktur geologi, geomorfologi dan iklim yang ada di Indonesia. Pelajaran sejarah yang patut diambil adalah agar manusia Indonesia selalu waspada dan terus berupaya agar semakin cakap dalam memitigasi dan mengurangi sekecil mungkin kerugian akibat bencana.

\section{DAFTAR PUSTAKA}

Chambert-Loir, Henri. 2004. Kerajaan Bima dalam Sastra dan Sejarah. Jakarta: Kepustakaan Populer Gramedia Ecole francaised'Extreme-Orient

Emalia, Imas. 2020. Wabah Penyakit \& Penanganannya di Cirebon 1906-1940. Yogyakarta: Penerbit Ombak.

Harari, Yuval Noah. 2019. Homo Deus: Masa Depan Umat Manusia. (penerjemah Yanto Musthofa). Jakarta: Penerbit Alvabet.

Kartodirdjo, Sartono. 1984. Pemberontakan Petani Banten 1888. Jakarta: Penerbit Pustaka Jaya.

Lapian, A.B. 1984. "Bencana Alam dan Penulisan Sejarah (Krakatau 1883 dan Cilegon 1888)" dalam Teuku Ibrahim Alfian dkk editor. Dari Babad dan Hikayat sampai Sejarah Kritis. Yogyakarta: Gadjah Mada University Press: 211-231.

Penders, C.L.M. 1984. Bojonegoro 1900-1942 A Story of endemic poverty in northeast Java- Indonesia. Jakarta: PT Gunung Agung bekerjasama dnegan PT Inti Idayu Press.

Sjamsuddin, Helius. 2013. Memori Pulau Sumbawa Tentang Sejarah, Interaksi Budaya \& Perubahan Sosial-Politik di Pulau Sumbawa. Yogyakarta: Penerbit Ombak.

Sudradjat, Adjat \& Heryadi Rachmat. 2015. Greetings from Tambora A Potpurri of the Stories on the Deadliest Volcano Eruption. Bandung: Geology Museum Center for Geological Survey, Geological Agency. 
Wibowo, Priyanto dkk. 2009. Yang Terlupakan Pandemi Influenza 1918 di Hindia Belanda. Depok: Kerjasama antara Departemen Sejarah Fakultas Ilmu Pengetahuan Budaya Universitas Indonesia, Unicef Jakarta dan Komnas FBPI.

Zuhdi, Susanto. 2006. "Perspektif Tanah-Air Dalam Sejarah Indonesia" Pidato Pengukuhan Guru Besar Tetap Fakultas Ilmu Pengetahuan Budaya Universitas Indonesia. Kampus UI Salemba, Jakarta 23 Maret.

Zuhdi, Susanto. 2016. Cilacap (1830-1952) Bangkit dan Runtuhnya Suatu Pelabuhan di Jawa. Yogyakarta: Penerbit Ombak.

\section{HASIL DISKUSI}

\section{Pertanyaan}

1. Nanang Saptono (Balai Arkeologi Jawa Barat)

Bencana alam mempengaruhi suatu kebudayaan. Ada faham-faham tentang itu Environmnetal possibilism dan Environmnetal determinism. Kaitannya dengan becana alam yang terekam adalah bagaimana peristiwa tersebut menimbulkan reaksi terhadap masarakat. Mohon tanggapanya

\section{Jawaban}

1. Pengetahuan untuk mengetahui transformasi di dalam kebudayaan memang masih sedikit. Kita punya kemampuan budaya tetapi memang harus diuji, karena bisa jadi ada kebudayaan yang tidak mau bertransformasi. Karena ada warisan perlawanan jadi struktur ingatan kolektif bisa tidak terwarisakan atau harus ditantang supaya menghasilkan rasionalitas yang bisa diterima. 